\title{
Pair Research Tasks: Promoting Educational Research with Pre-Service Teachers
}

\author{
Tareas de investigación en parejas: fomento de la \\ investigación educativa en profesores en formación
}

\author{
Eulices Córdoba Zúñiga ${ }^{1}$ \\ Isabel Zuleta Vásquez ${ }^{2}$ \\ Uriel Moreno Moreno ${ }^{3}$
}

Citation/ Para citar este Artículo: Córdoba, E., Zuleta, I., \& Moreno, U. (2021). Pair Research Tasks: Promoting Educational Research with PreService Teachers. Colomb. Appl. Linguistic. J., 23(2), pp. 196-212.

Received: 19-May.-2020 / Accepted: 29-Jun.-2021

DOI: https://doi.org/10.14483/22487085.16347

\begin{abstract}
This paper presents a study that explores the role of pair-work tasks to promote educational research in 20 pre-service English language teachers (eleven males and nine females) of a Colombian public university. The project was carried out to enhance educational research skills and knowledge by developing theoretical-practical pair-work research tasks. Data was collected through observation field notes, semi-structured interviews, and field journals. The results suggest that pair-work research tasks increased learners' opportunities to acquire theoretical and practical educational research knowledge and skills. Due to this exercise, the participants learned to define, formulate research objectives-questions, review the literature, and state research methodologies to finally write their research proposals. Additionally, pair-work research assignments offered an effective way to work together, negotiate, reach agreements, and gain experience by conducting theoretical and practical research exercises.
\end{abstract}

Keywords: academic research proposal, educational research, pair-work, research knowledge, task

\section{Resumen}

Este artículo presenta un estudio investigativo que explora el rol de las tareas en pareja para promover la investigación educativa en 20 profesores de inglés en formación (once hombres y nueve mujeres) de una universidad pública colombiana. El proyecto fue realizado para ampliar las habilidades y el conocimiento de la investigación educativa mediante el desarrollo de tareas de investigación teórico-prácticas de trabajo en pareja. La información se recopiló a través de notas de campo de observaciones, entrevistas semiestructuradas y diarios de campo. Los resultados sugieren que las tareas de investigación en parejas aumentaron las oportunidades de los estudiantes para adquirir conocimientos y habilidades en investigación educativa. Debido a esa práctica, los participantes aprendieron a definir, formular objetivos-preguntas de investigación, revisar la literatura y plantear metodologías de investigación para finalmente redactar sus propuestas de investigación. Las asignaciones en

1 Universidad de Antioquia and Corporación Universitaria Adventista. ORCID (iD: https://orcid.org/0000-0002-3985-9571. eulices. cordoba@udea.edu.co / docente.ecordoba@unac.edu.co / eucorzucho@gmail.com.

2 Universidad de Antioquia. ORCID (D): https://orcid.org/0000-0003-4203-464. isabelavasquez@gmail.com .

3 Universidad Tecnológica del Chocó Diego Luis Córdoba. ORCID (D): https://orcid.org/0000-0003-4203-464X. d-uriel.moreno@utch. edu.co. 
parejas ofrecieron una manera eficaz de trabajar juntos, negociar, llegar a acuerdos y ganar experiencia mediante la realización de ejercicios de investigación teóricos y prácticos.

Palabras clave: propuesta de investigación, investigación educativa, trabajo en pareja, conocimiento de investigación, tarea

\section{Introduction}

Promoting research in undergraduate programs is an essential component of the training process. Such knowledge allows students to reflect upon their future practice, learn about the theory of inquiry, and how to use that insight to interpret classroom difficulties practically. In a study regarding research, Edwards (as cited in Reyes-Cruz et al., 2017) stated that undergraduate education programs enable pre-service teachers to solve teaching and learning challenges, in addition to "encouraging preservice teachers to do research provided reflective practice" (ViáfaraGonzález, 2008, p. 2). Based on Decree No. 2566 (2003) from the Colombian Ministry of Education (MEN), training learners in research can produce new knowledge and grant access to scientific information. In this vein, developing research in undergraduate English as a Foreign Language (EFL) learners would be a possibility to broaden their theoretical constructs of research, examine the implications of conducting it, and analyze the ways to integrate inquiry into the teaching and learning practice.

In reflections analyzing research, Hensel (2012), Petrella and Jung, (2008), and Blank (1982) agreed that this component is fundamental for a high impact in undergraduate programs. In this perspective, we consider that promoting research plays a significant role in training teachers. First, this knowledge enhances the understanding of the teaching profession by means of constant reflections on approaches, methods, or techniques that can be used to overcome teaching and learning challenges. Secondly, inquiry offers the possibility to exchange ideas, learn from the results of others, negotiate, and work with others to gain experience in order to self-evaluate teaching practices. Thus, educating undergraduates in research components inspires a new understanding of the teaching and learning processes, helps overcome difficulties in the area, and generates research proposals.

On the other hand, Castro-Garcés and Martínez-Granada (2016), Fagan (2015), Akyel (2015), and Banegas (2012) ascertained that in the particular context of EFL programs, encouraging research would enhance undergraduates' possibilities to develop insights into language teaching. These insights would help students self-evaluate their future EFL practices, foster teamwork, and reflect on what they do in the EFL classrooms. However, we realized that 20 trainee teachers from the EFL undergraduate program of a public university had multiple difficulties in formulating a research proposal. They struggled to choose and define their research topics, stating research objectives and questions, conducting literature reviews, and formulating the methodology of their proposals.

The worst thing was that they had to present said research proposals as an option to graduate in that semester. Therefore, we needed to find an alternative to meet this university requirement and teach them how to do research. One of the researchers had a previous experience with pairwork and proposed it as a plan to help overcome this dilemma. Then, pair-work assignments were considered as an opportunity to overcome the barriers these pre-service teachers had. On pair-work research, Sert (2005); Raja and Saeed (2012), and Córdoba (2013) suggested that such methodology contributed to enrich cooperative work, social interaction, and enrich classroom performance. Nevertheless, such findings seemed not to be put into context. Therefore, we decided to apply pairwork research assignments as an opportunity to broaden the theoretical and practical usability of research and overcome the barriers these preservice teachers presented. Thereupon, this research attempts to find an answer to the research question: To what extent do pair-work assignments promote educational research in undergraduate pre-service EFL teachers? 


\section{Theoretical framework}

\section{Educational research in undergraduate programs}

There has been an increasing amount of literature on undergraduate research as a critical component in initial teacher education (e.g. Blank, 1982; Hensel, 2012; Walkington, 2015; Petrella and Jung, 2008). These authors all agree that research creates academic environments to understand teaching and learning processes better and enhance teaching reflection. In our perception, research encourages undergraduates to learn how to use academic-scientific works, helps them discover their research interests, and provides opportunities to start a possible research career. Furthermore, research enables learners to use research results and interpret scientific knowledge with a certain degree of confidence, and it fosters undergraduates' capacities to integrate theory and practice.

Additionally, Hensel (2012) states that undergraduate research captures students' interest and creates enthusiasm for making an original intellectual or creative contribution to their field. Petrella and Jung (2008) say that "incorporating a research component (...) allows students to develop independent critical thinking skills along with oral and written communication skills. The research process impacts valuable learning objectives that have lasting influence as undergraduates prepare for professional service" (p.1). According to Blank (1982), this component encourages the practice of theoretical and practical tasks that simulate difficulties which need to be solved or analyzed from multiple perspectives.

Undergraduate research is essential for fostering a research culture that provides highquality research experiences for students, along with a broad disciplinary understanding in the field. Encouraging such knowledge may be a way to successfully articulate the mission, vision, and strategic plans of the institution. Adopting research may be a pivotal component to mobilize the possibilities of undergraduate education programs to help develop education and foster critical thinking among the pre-service teachers. We defend a critical research perception as a component that generates opportunities to develop critical thinking, reflection, innovation, and disciplinary understanding.

This research perspective is shared by CárdenasRamos and Faustino (2003), Akyel (2015), Allison and Carey (2007), Banegas (2012), Benson et al. (2009), Borko et al. (2007), Borg (2009), Fagan, (2015), and Castro-Garcés and Martínez-Granada, (2016). They agree that such knowledge encourages permanent academic and pedagogical examination of problems to discover intellectual responses and make decisions in the field of education. In this sense, research helps learners become aware of the need to conduct constant reflection in education. This perspective suggests that research is a meaningful alternative for EFL undergraduates to empower the EFL learning process, increase undergraduates' knowledge about language, the theories about language learning, and the methodologies applied to foster EFL learning and teaching.

Based on the previous perspective, we are clearly in contrast with what the American Educational Research Association (AERA) (2020) stated as educational research. They expressed that this is a careful, systematic, and reflective process that provides reliable contributions by developing flexible examination that offers measurable and statistical interpretations of data to overgeneralize results. We confronted Ary et al. (2018) when they stated that "(...) the scientific approach is regarded as the single most reliable source of new knowledge" (p. 20). For them, research is a scientific field of study that embraces the full spectrum of rigorous methods that answer questions and drive new tools and techniques. However, we believe that more than discovering realities, it is about assuming statistical interpretations as facts that represent situations or embracing the full spectrum of rigorous methods to respond to the research questions appropriately. Research, especially in education, offers the possibility to understand human behavior and the interaction process to assume a reflective perspective about human perceptions, about a problem, and to provide various interpretations of data by using prolonged engagements. Thus, we may state that enhancing education research helps foresee, clarify, associate, and analyze how to improve the teaching and learning process both analytically and critically. 


\section{Pair-work assignments}

Pair-work assignment is a teaching and learning strategy that increases student-centered classes, enriches classroom environments, raises motivation, and enhances class productivity. Several studies (Sert, 2005; Raja and Saeed, 2012; Córdoba 2013) define pair-work as a teaching technique that increases opportunities to develop intellectual capacities. In this context, it "creates a high level of academic solidarity and confidence which increases task development" (Sert, 2005, p. 1). Moreover, Córdoba 2013 concluded that this method allows students to work together, assume responsibilities for their learning process, and expand their knowledge through constant negotiation with their classmates. Thus, teamwork has become an alternative method to clarify, double-check, and finish assignments by interacting, working cooperatively, and making decisions on how to submit a task.

We agree that this method, as a teaching and learning methodology could strengthen research and facilitate the construction of theoretical and practical knowledge. Kutlay (2013), Lombard and Kloppers (2015), Lopatto (2003), McNulty Ferri (2010), Mello et al. (2008), and Raja and Saeed (2012) all conclude that group work assignments are an opportunity to apply what the prospective teachers are learning: "pair work provides different alternatives to foster learning" (Bercicova,2007. p.22). Achmad (2014) explains that pair-work assignments are a valuable teaching strategy that empowers classroom interaction, self-directed work, and independence, in addition to lessening teachers' class involvement.

Equally important, students who are less competent in research can receive support from their classmates to become proficient in this area. This point of view is related to a well-known theory (the zone of proximal development) proposed by Vygotsky (1998), which "says that if a more competent person and a less competent person face a task, the less competent person becomes independently proficient at what was initially a jointly accomplished task" (Chaiklin, 2003, p. 2). In this sense, group work seems to be an option to foster research knowledge. If one student does not possess the knowledge to comply with the tasks, a classmate can help him/her overcome the barriers. The students would then cooperate to learn from each other and grow when they work alone to encourage the learning process. This study suggests that this strategy would significantly encourage such knowledge in 20 trainee teachers because pair-work seemed to be a possibility of developing tasks with a higher level of success and increasing opportunities to become independent and grow into research. However, there is no theoretical evidence that ascertains the importance of such tasks to promote research in forthcoming teachers.

\section{Methodology}

This study used qualitative analysis to gain insights into the effectiveness of pair-work tasks to encourage educational research in 20 pre-service EFL teachers of a public university. Berg and Lune (2004) and Brydon-Miller et al. (2003) state that this approach helps educational researchers to holistically examine problems from their practice.

\section{Research context and participants}

This study took place at a public university located in Florencia, Colombia. The institution has a Department of Education Sciences that offers over five undergraduate degree programs: Social Sciences, Mathematics, Spanish and Literature, Child Pedagogy, and the EFL Program. The study plan suggests that the students complete two research courses, submit and implement a research proposal, and socialize its results to get the bachelor's degree in EFL. Consequently, when the undergraduates are taking the fifth semester, they are supposed to learn educational research theory and submit a research proposal in the sixth semester. Then, in the seventh and eighth semesters, the students need to implement their research proposals. Finally, in the ninth semester, they socialize their results. The participants of this study were 20 undergraduates, whose age ranged between 20 and 25 years old. In addition, there were twelve females and eight males who showed a shared willingness to overcome their barriers in order to complete a research proposal. 


\section{Data collection instruments}

We used three different instruments to gather information: observations, interviews, and field journals. Firstly, we conducted classroom observations to understand the attitudes, behavior, feelings, and types of ongoing interactions during the assignments. Jacobson et al. argue that "the use of observation provides direct access to the phenomenon under consideration by providing accurate and complete information from the participants' behavior" (as cited in Córdoba, 2016, p. 6). The authors support this instrument with semistructured interviews. On his part, Wengraf (2001) shows that this method is an indispensable way to collect qualitative data and improve knowledge of the phenomenon under research. DiCicco-Bloom and Crabtree (2006) conclude that this kind of interview is a meaningful way to collect qualitative data. Based on that, we conducted six interviews with the undergraduate learners.

\section{Procedures to implement the task in EFL}

To carry out the study, we followed three steps and invested 60 hours. During step one (pair-work assignment organization), the researchers explained each of the ten research tasks, the objectives, and the criteria of the exercises. Then, we negotiated the deadlines and the amount of time available for each work (see Appendix 1: List of Pair-work assignments with aims and expected results). For step two (pair-work assignment development), the students performed their corresponding tasks. Meanwhile, they exchanged their ideas with other pairs and submitted their draft reports. At this stage, they also discussed with other teams to refine their work. In step three (pair-work assignment presentation), the undergraduates presented their written reports based on the criteria designed for each activity. Then, the researchers gave the information back to the students and asked them to correct them with different pen colors. They also had to self-evaluate their performance while completing the tasks. Once the learners did that, the researchers checked the written reports, and the undergraduates received meaningful feedback.

\section{Data analysis}

This section provides an overview of the process for analyzing the data that we collected, examined, compared, and contrasted, to finalize with the emergent theoretical model, as shown in Table 1 along with the procedures followed.

All observations and interviews were audiovideo taped and lasted approximately 40 minutes. They served to obtain reliable information about the efficacy of tasks to enhance research abilities. We then contrasted the data obtained from these sources with the researchers' field journals. Wallace (2008) states that this technique allows researchers to collect essential data, especially in qualitative research studies. Moreover, "keeping and using the journal in the qualitative research process creates transparency in the research process and explores the impact of critical self-reflection on research design" (Ortlipp, 2008, p. 1). In addition, this process allowed the researchers to keep a written reflection and record of the usefulness of pair-work

Table 1. Grounded theory analysis process

\begin{tabular}{|c|c|c|c|}
\hline Data collection & Analysis & Findings & $\begin{array}{c}\text { Emergent theoretical } \\
\text { model }\end{array}$ \\
\hline $\begin{aligned} \text { Procedure } & \\
\bullet & \text { Observations } \\
\bullet & \text { Semi-structured Interviews } \\
& \text { Field journals } \\
\text { Results } & \\
\bullet & \text { Transcripts } \\
\text { - } & \text { Documents }\end{aligned}$ & 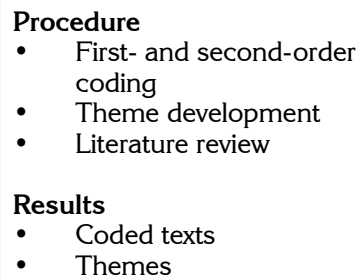 & $\begin{array}{l}\text { Procedure } \\
\text { Description of the } \\
\text { themes } \\
\text { Results } \\
\text { Description of the } \\
\text { themes }\end{array}$ & $\begin{array}{l}\text { Procedure } \\
-\quad \text { Linking identified } \\
\text { themes } \\
\text { Results } \\
-\quad \text { Coherent framework }\end{array}$ \\
\hline
\end{tabular}

Source: Authors 
assignments to promote research, as well as to collect information during a continuous process. We transcribed all the information into Microsoft Word documents, marked each document with names, dates, and organized them in different files (interviews, observations, and journals).

We started the analysis by coding the transcribed data inductively. At this stage, we identified the initial categories without using prior codes. In the following step, we implemented selective coding to integrate the initial codes into more elaborated patterns to form coherent theoretical categories. We then reviewed the literature to contrast the information by using constant comparison to adequately examine the participants' perception of the research process. Glaser (2007) argues that constant comparison is a research method that enhances validity and trustworthiness to data analysis. Table 2 relates what we found from the initial codes to the literature review.

\section{Findings}

The data analysis and interpretations followed the principles of grounded theory. Consequently, we collected the data, transcribed it, labeled it, and coded it on Word documents with names, dates, and purposes. Once we organized the information, we grouped and wrote the initial concepts. Then, categories emerged from the ideas: initial and repeating codes (codes and segments). We elaborated meaning and links among their types to construct the theoretical descriptive and explanatory model. Then, we went back and forth to compare and redefine categories, concepts, and interpretations based on the ideas, codes, and segments. The grounded theory "provides an explanatory framework to understand the phenomenon under investigation, so it helps to identify, refine and integrate categories, and ultimately to develop theory" (Strauss and Corbin, 1994, p. 70). This method helps researchers "decide

Table 2. Examples of what was found in each step (initial categories, selecting codes, coherent theoretical categories, and literature review)

\begin{tabular}{|c|c|c|c|}
\hline Initial categories & Selective coding & $\begin{array}{l}\text { Coherent } \\
\text { theoretical } \\
\text { categories }\end{array}$ & Literature review \\
\hline 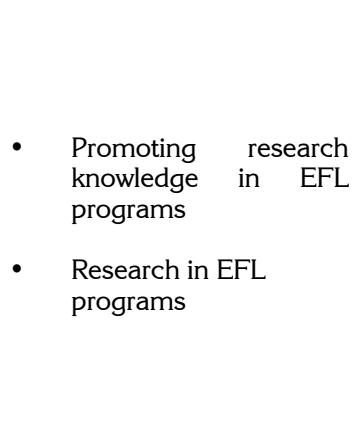 & $\begin{array}{l}\text { - } \text { Increases research knowledge. } \\
\text { Facilitates practical and theoretical } \\
\text { rehearsal. } \\
\text { - } \quad \text { Helps identify research characteristics } \\
\text { and processes. } \\
\text { - Facilitates research involvement. } \\
\text { - } \quad \text { allows research experience. } \\
\text { proposals. }\end{array}$ & $\begin{array}{l}\text { Promoting research } \\
\text { in the EFL program. }\end{array}$ & 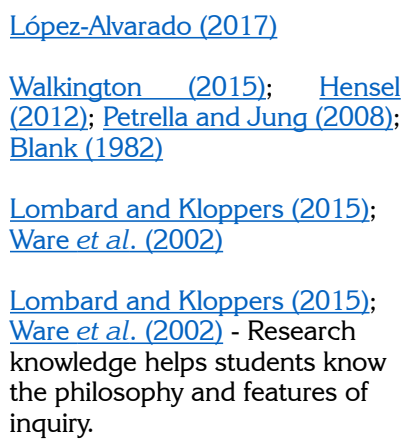 \\
\hline $\begin{array}{l}\text { - Applying pair-work } \\
\text { research tasks } \\
\text { in this group of } \\
\text { undergraduates. } \\
\text { - Pair-work researchtasks } \\
\text { in undergraduates. }\end{array}$ & $\begin{array}{l}\text { - Facilitates opportunities to develop } \\
\text { practical tasks. } \\
\text { Offers possibilities to do theoretical and } \\
\text { practical tasks. } \\
\text { Helps overcome weaknesses to conduct } \\
\text { research. } \\
\text { Augments opportunities to conduct } \\
\text { research proposals collaboratively. } \\
\text { Enhances possibilities to exchange } \\
\text { research ideas. }\end{array}$ & $\begin{array}{l}\text { Applying pair-work } \\
\text { research tasks as a } \\
\text { way to enhance EFL } \\
\text { research. }\end{array}$ & 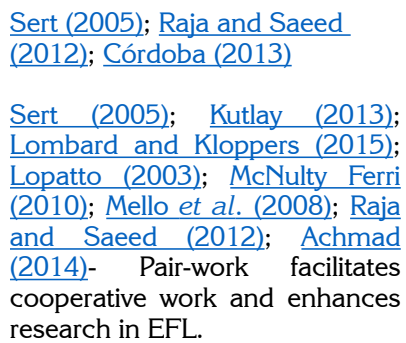 \\
\hline
\end{tabular}

Source: Authors 
on the codes to be used, to group the information into categories and subcategories, and to integrate codes for analysis" (Pérez and Alvira, 2017, p. 109). In this regard, Kreiner et al. (2006) suggested three phases. First, coding shows the list of codes. Next, the themes, in which the first codes make significant themes. Thirdly, the codes and themes help develop categories, as demonstrated by Table 3 .

\section{Promoting research in the EFL program}

This category was created with three main themes (research knowledge, benefits of conducting research, and learning about the research process in detail) and eleven repeating codes supporting these statements. Each of the themes will be explained below.

\section{Research knowledge}

Informants emphasized that promoting research knowledge led them to care about the theory and practice of research as the main component to reflect upon the teaching and learning process. They increased their research knowledge by developing tasks that demanded that they understood what research is and the implications of integrating such knowledge in the field of education.

Participant 1 stated that the formation in educational research was a good way to learn about the theory of research, its principles and its basic characteristics (interview 2).

Participant 2 considered that enhancing educational research knowledge helped have a general understanding of what research entails in terms of benefits for education (interview 5).

Participant 3 explained that expanding his background in research let him open his conception about this important component of professional development. He learned research has different ways to get a better understanding of a problem or difficulty (interview 3).

The participants shared this perception about research knowledge because it made it possible to get acquainted with the principles, philosophy,

Table 3. List of codes, themes, and categories

\begin{tabular}{|c|c|c|}
\hline Codes & Themes & Categories \\
\hline $\begin{array}{l}\text { - } \quad \text { Facilitates opportunities to achieve research competencies } \\
\text { - } \quad \text { Practical and theoretical assignments help foster research } \\
\text { - } \quad \text { Helps realize the importance of EFL education }\end{array}$ & Research knowledge & \multirow{3}{*}{$\begin{array}{l}\text { Promotes research in the EFL } \\
\text { program }\end{array}$} \\
\hline $\begin{array}{l}\text { - } \quad \text { Helps identify research characteristics and processes } \\
\text { - } \quad \text { Facilitates more research involving } \\
\text { - } \quad \text { Helps develop theoretical and practical research assignments } \\
\text { - } \quad \text { Enlows learners to know about the usability of research } \\
\text { Enables students to have research accountability }\end{array}$ & $\begin{array}{l}\text { Benefits of conducting research } \\
\text { and learning about the research } \\
\text { process in detail }\end{array}$ & \\
\hline $\begin{array}{l}\text { - Offers opportunities to explore foreign language research } \\
\text { - } \quad \text { Benefits the EFL education program and profession }\end{array}$ & $\begin{array}{l}\text { Explores foreign language } \\
\text { research process }\end{array}$ & \\
\hline $\begin{array}{l}\text { - Enhances understanding of the EFL education process } \\
\text { - Understands the EFL education process } \\
\text { Gains insights from their classmates, teacher-researches, } \\
\text { and the reading material }\end{array}$ & $\begin{array}{l}\text { Pair-work as a way to foster EFL } \\
\text { research education }\end{array}$ & \multirow{2}{*}{$\begin{array}{l}\text { Applies pair-work research } \\
\text { tasks as a way to enhance EFL } \\
\text { research }\end{array}$} \\
\hline $\begin{array}{ll}\text { - } & \text { Increases opportunities to exchange research ideas } \\
\text { - } & \text { Augments negotiate among classmates } \\
\text { - } & \text { Expands peer-correction and productions } \\
\text { - } & \text { Receives more insights to do each task } \\
\text { Fosters knowledge on how to develop research proposals }\end{array}$ & $\begin{array}{l}\text { Pair-work research assignments } \\
\text { as a possibility to conduct } \\
\text { research proposals }\end{array}$ & \\
\hline
\end{tabular}

\section{Source: Authors}


procedures, and the implications of such knowledge in the field of education. Research principles allow for a synthesis, analysis, and reflective process that increases their understanding of how and why research needs to be incorporated in an education program. In our view, knowing about the principles of research allowed pre-service teachers to realize that this component is a fundamental way to critically understand the behavior of human beings, as well as to collect, analyze, and interpret data ethically. Promoting such knowledge allowed students to realize that educational research, rather than being a rigorous process of systematic data measurement, is a process that seeks to understand the forms of interaction that take place in educational contexts.

The participants realized that research demands good practices, such as ethical consideration guidelines that confidentially protect data, seek consent, and take care of the participants. Another reason that may explain why the pre-service teachers became concerned about research is that they learned about research philosophies. They understood the most critical assumptions that determine a research philosophy, such as the ontology, epistemology, and axiology of qualitative research. These assumptions were more than basic research concepts, terminologies, or principles, and they helped learners realize that qualitative research demands that researchers understand social phenomena and social interaction. Equally important, qualitative research demands that they get involved in the research process as another member. It is also important to understand that the data collection process is varied, and data analysis and interpretation are subjective.

Consequently, we may state that promoting research among the pre-service EFL teachers was a fundamental way for them to learn about the logical, systematic principles and processes that research demands. They fulfilled assignments that required them to read about research, its importance in academic life, and the practical research processes to elaborate research proposals. The participants got acquainted with the methodologies of research, as well as with its types and purposes. The findings of our study seem consistent with those of López-Alvarado (2017), who explained that educating learners about research trains them to know about philosophies and research methodologies. In this regard, Walkington (2015), Hensel (2012), Petrella and Jung (2008), and Blank (1982) all agree that enhancing research was essential to broaden academic and scientific interpretations in the initial undergraduate learning process. Promoting such knowledge was a valuable opportunity to have hands-on experience that allowed the participants to expand what they already knew about inquiry. We cannot extrapolate this finding to all the contexts and pre-service EFL teachers, given that, in this study, the contestants had a previous research background, which helped them perform the research tasks easily. However, this study seemed to be a significant opportunity to expand the undergraduates' theoretical knowledge of educational research and gain practical experiences to develop research processes.

\section{Benefits of conducting research in an education program}

Enhancing research aided the participants in discovering the practical implications of research, in expanding their knowledge of education, and in better understanding teaching and learning theories as well as teaching as a profession. They also understood how researchers examine problems or difficulties that appear in their academic field.

Participant 6 realized that

research is a fundamental way to examine problems, seek solutions, and broaden his understanding of teaching profession. Moreover, by receiving such education he found out the specific elements needed to conduct research. For example, that many research methods have particular ways to collect information, select participants, and analyze data (interview 4).

Participant 8 agreed that

Studying research allowed me to recognize that to conduct this process, I need to identify a problem, review literature, set questions-objectives, choose appropriate methodology, collect and analyze data and finally come out with the results, conclusions, and recommendations (interview 4). 
The data revealed that promoting research in undergraduate EFL teachers significantly broadened the experience and expertise in research topics and processes. Pre-service teachers expanded their research experiences and went through each inquiry stage by developing activities that led them to learn about the different parts of the research process (see Appendix 2). Another important reason was that research education provided opportunities to the contestants in order for them to broaden their research comprehension by developing diverse exercises such as reading, writing, discussions, and debates. Reading, writing, and oral exercises were alternatives that the pre-service teachers used to expand their research experiences and promote helpful knowledge in each stage of an inquiry. Such knowledge enlarged the learners' backgrounds to select the methodology of the study and observe the benefits of other research processes such as literature reviews. Most students referred to the benefits of research as a possibility to increase knowledge and foster competencies to analyze, understand, or overcome difficulties. In our perception, the training process they had in this study was appropriate for identifying a research problem or theme and reviewing the literature by developing the aforementioned exercises.

In the same way, it was a way to learn how to state questions and objectives, select the methodology, and collect, analyze, and process data. In recent research on the implications of promoting research in pre-service teacher education, Lombard and Kloppers (2015) and Ware et al. (2002) showed that such knowledge was a fundamental element to fostering professional development and offered possibilities to reshape the teaching practice. However, this study did not find a significant relationship between fostering research and promoting professional growth. Instead, we observed that enhancing such content was a way to reflect upon the benefits of research as a significant cluster of finding ways to understand or interpret the consequences of a problem, which does not necessarily imply a way to grow professionally. That is why we consider that more studies are necessary to examine that effect.

\section{Exploring the foreign language research process}

The data revealed that promoting such knowledge in undergraduate EFL teachers led to exploring the EFL research process. The learners developed theoretical and practical assignments to conduct research processes in order to explore how the foreign language research theory and processes contribute to them and the field.

\section{Participant 11 claimed that}

the project was essential to increase research knowledge about foreign language teaching and learning philosophies. The project was a great possibility to learn about the theory of research and practical ways to overcome research weaknesses to define a problem, state a research objective, conduct a literature review, and select a methodology for a study (interview 6).

Participant 10 confirmed that promoting educational research in undergraduates was a good way to learn how to overcome problems that might have in his future career as a teacher (interview 2).

During the classroom observations (five and six), we could see the participant sharing and discussing the research assignments. In addition, the researchers found and wrote in their journals that educational research in undergraduates facilitated more research involvement, and the students performed real tasks, in which research proposals were constructed step by step (interview 5).

The participants highlighted that exploring the foreign language research process is one of the benefits of promoting research in this context because it was an alternative for them to know more about EFL teaching and learning. Along this process, they reviewed EFL teaching and learning theories, and they identified ways to implement them in practical research. They realized that doing practical and theoretical exercises allowed them to analyze how they would use those studies to enhance learning possibilities. To this effect, they read and wrote collective reports to participate in theoretical and practical discussions and reflections 
on how to overcome classroom problems. After this discussion, they started to define a research problem, state a research objective, conduct a literature review, and select the methodology of the study (see Appendix 2).

In our perception, those exercises, activities and tasks led the pre-service teachers to strengthen research in foreign language education and let then create a scenario from where they gained experience on theories of foreign language acquisition, teaching, and learning by providing a framework of references of most influential authors, current tendencies, and the pedagogical implication of said theories to better understand the fields of phonology, morphology, syntax, semantics, and pragmatics. Previous studies have demonstrated that research knowledge in EFL should lead pre-service teachers to comprehend their future professions well (e.g. Elliot, 1990; Gitlin et al., 1999); Viáfara-González, 2008; Guerra-Sánchez et al., 2015; Hagevik et al., 2012). From our viewpoints, research knowledge in EFL education should seek out advances in EFL teaching-learning processes and in understanding the teaching profession. In this regard, ViáfaraGonzález (2008), Cárdenas-Ramos and Faustino (2003), and Weinberger et al. (2016) agreed that research knowledge in EFL education promotes reflection and skillful conceptualization about the profession.

Another possible explanation for such a finding would be that exploring foreign language research encouraged the participants to examine language skills (listening, speaking, reading, and writing). They found that an EFL teacherresearcher needs to master his/her field of study satisfactorily. According to Reyes-Cruz et al. (2017), Zheng (2009), Price (2001), Pellerin and Nogués (2015), Mello et al. (2008), and Mehrani (2015), EFL research generates suitable academic environments to transform EFL teaching and learning processes. Educating pre-service teachers in these subjects increased the participants' reflections; it made them aware of the need to learn how to seek solutions to the possible problems they may find in the teaching and learning process. This process allowed prospective EFL teachers to gain more insights about their professions and broaden their perspectives about the benefits of research to facilitate EFL education processes.

\section{Applying pair-work research tasks as a way to enhance EFL research}

This category emerged after contrasting the information gathered and grouped into two subcategories: pair-work to foster EFL research education and pair-work research assignment as a possibility to elaborate research proposals.

\section{Pair-work as a way to foster EFL research education}

Data analysis revealed that pair-work seemed to be an effective methodology to enhance EFL research education in this particular context and in undergraduate students. This method facilitated opportunities to work cooperatively and gain more theoretical and practical insights in order to broaden research perceptions, understand the importance of inquiry in the EFL education process, and discover the impacts of such knowledge in foreign language teaching and learning. Additionally, the methodology promoted teamwork, exploration, and interaction, which led the participants to exchange research ideas, materials, and initiatives. It also develops brainstorming exercises and work as a team to performed each research task, which broadened their perceptions and understanding of the research characteristics and their importance in the EFL education process.

Interviewee 20 explained that working with a classmate helped realize the importance of research as a way to solve problems, get acquainted with the EFL profession, and develop research assignments (interview 5).

Participant 12 believed that pair-work tasks strengthened research because working together and receiving support from his classmates was fundamental to do the scheduled tasks (interview 5).

Participant 11 acknowledged that the theoreticalpractical tasks developed provided different learning experiences that helped develop his skills to define, formulate research objectives and questions, review literature, and state research methodologies (interview 5). 
The findings suggest that pair-work was an alternative to foster EFL research education among the 20 participants in the study. We found that these assignments offered possibilities to get acquainted with theoretical and practical research by offering different activities and exercises to do practical research tasks. The participants had more exposure to research concepts, processes, implications, and opportunities to explore the benefits of research in their future careers as teachers. As an example, they had more opportunities to exchange research ideas for materials and initiatives, and they developed assignments that were oriented towards fostering teamwork, exploration, and interaction. This led to discussions about the roles of EFL research, its impact in foreign contexts, and how to integrate research knowledge to examine teaching-learning problems.

During these tasks, we noticed that students worked together, negotiated, and reached agreements about how to have research accountability, how to discuss how to conduct research, and how to learn about the research process in detail. In addition, pre-service teachers participated in oral debates, writing reports together, and asking and answering questions to clarify research concepts and practical usage. Interestingly, there was a close relationship between these findings and those presented by Sert (2005), Raja and Saeed (2012), and Córdoba (2013), who clarified that pair-work tasks enhance class productivity. Such relationships were presented mainly because pair work research tasks increased possibilities to conduct research proposals collaboratively. The participants negotiated, interacted, reached agreements, and self-evaluated their tasks before submitting or receiving clarifications from the researchers.

\section{Pair-work research assignment as a possibility to conduct research proposals}

The data analysis revealed that pair-work assignments had a positive impact on promoting EFL research education. The participants constantly participated in theoretical and practical exercises, discussions, and works to increase their insights into EFL research and its characteristics, process, and methodology. Pair-work tasks offered possibilities to get acquainted with the theoretical and practical research usage and encouraged them to learn from each other, correct their work, and, as a consequence, enlarge their research background to complete a proposal (see Appendix 2). Theoretical and practical research rehearsal enhanced constant pair discussions and negotiations on elaborating research proposals and assuming research as a possibility to know more about how to teach English as a foreign language and a way to appreciate research as a vehicle to mobile language teaching and learning.

Based on the above mentioned, we believe that pair-work research tasks encouraged practice and exposure to research through self-directed work and independent theoretical and practical assignments, which led future teachers to overcome their difficulties in incorporating research knowledge into practice. Pair-work research assignments offered practical exploration that encouraged negotiation, critical thinking, and practicing shared reading and collaborative writing. These assignments enhanced the students' familiarity with research and empowered and broadened their understanding to write their own research proposals. The pre-serviceteachers showed significant improvements that helped them expand their capability in EFL research. In this sense, the methodology was significant because it increased the students' opportunities to double-check their tasks, share research ideas, do negotiated tasks, reach agreements, and work cooperatively with their peers.

The above-mentioned finding is associated with Sert (2005), who insisted that this methodology creates a high level of academic solidarity and confidence (p. 1). In this regard, Kutlay (2013), Lombard and Kloppers (2015), Lopatto, (2003), McNulty Ferri (2010), Mello et al. (2008), and Raja and Saeed (2012) manifested that pair-work assignments may promote research in pre-service EFL teachers. This result confirmed that working together made it easier for pre-service teachers to integrate different backgrounds, foster decisionmaking, create group environments where they incorporated various perspectives. Learners overcame their difficulties in understanding the 
main content of a research proposal and opened up respectful communication that contributed to satisfactorily completing their tasks and elaborating their proposals.

\section{Conclusions and implications}

The analysis showed that the project seemed to be an essential response to promoting research by completing academic and practical research assignments. First, this study was a meaningful way to realize that research is a vehicle to examine, synthesize, evaluate teaching and learning practice, and enhance reflection in education. In addition, the tasks promoted a better understanding of the research knowledge, its processes, methodologies, and characteristics that need to be considered while conducting an inquiry. It was also essential to foster ethical research principles and the alternatives to conduct an inquiry in education, as well as to reflect upon the benefits of this academic insight. However, acquiring research is not only decoding or mastering its structure. Pair work gave contestants the chance to practice, discuss, and reflect on how they could integrate such components in their future professional careers. In this sense, the study indicated that pair-work was a significant methodology to boost educational research.

Secondly, pair-work research assignments were opportunities to overcome the participants' research difficulties before the project and offered possibilities to conduct research proposals. Said assignments created a class environment where theoretical and practical exercises demanded participation, collaboration, and negotiated exploration. The participants cooperated in expanding their ability to identify a problem, formulate research objectives-questions, conduct a literature review, write the methodology of a study, and develop a research proposal. This practical and cooperative theoretical exploration led them to have significant improvements in defining, formulating research objectives and questions, conducting literature reviews, and stating the methodology of a research proposal. This interaction trains them to complete their research proposal, which is one option that the university gives to graduate as a bachelor in
EFL. The tasks were planned and designed for them to not only learn the importance of inquiry, but also to complete a research proposal. The pairwork assignments were indeed a successful way to foster research. The participants wrote research titles, introductions, justifications, objectives and questions, conducted literature reviews, and proposed the methodology for their projects. These two capabilities played a prominent role in enhancing research comprehension and developing tasks properly.

Finally, conducting this study showed the various implications of fostering research in such a context. Firstly, pair-work assignments could become a flexible, creative, and multifunctional methodology oriented towards enabling undergraduates to get acquainted with research and overcome research difficulties collaboratively. Pre-service teachers might also understand the importance of sharing, discussing, and negotiating ideas to learn about the research process from others. Secondly, the evidence suggests that pairwork research assignments seemed to be an effective method that develops opportunities for preservice teachers to achieve theoretical and practical research competencies, promote educational research in undergraduate programs, and increase undergraduate's possibilities to master the research process. Therefore, it would be necessary to apply pair-work research tasks in other contexts and with different students to analyze whether or not this method may enrich the theoretical literature of EFL research mediated by teamwork.

\section{References}

Achmad, D., \& Yusuf, Y. Q. (2014). Observing pair-work tasks in an English-speaking class. International Journal of Instruction, 7(1), 151-164. http://files.eric. ed.gov/fulltext/EJ1085253.pdf

Akyel, A. (2015). Research Engagement in the EFL PreService Practicum. Language in Focus, 1(1), 1-14. https://doi.org/10.1515/lifijsal-2015-0001

Allison, D., \& Carey, J. (2007). What do university language teachers say about language teaching research? TESL Canada Journal, 24(2), 61-81. https://doi. org/10.18806/tesl.v24i2.139 
American Educational Research Association (AERA) (2020). Educational Research. https://www.aera.net/ About-AERA/What-is-Education-Research

Ary, D., Jacobs, L. C., Irvine, C. K. S., \& Walker, D. (2018). Introduction to research in education. Cengage Learning.

Banegas, D. L. (2012). Identity of the teacher-researcher in collaborative action research: Concerns reflected in a research journal. Profile Issues in Teachers Professional Development, 14(2), 29-43. https:// revistas.unal.edu.co/index.php/profile/article/ view/34051/34159

Benson, P., Chik, A., Gao, X., Huang, J., \& Wang, W. (2009). Qualitative research in language teaching and learning journals, 1997-2006. The Modern Language Journal, 93(1), 79-90. https://doi. org/10.1111/j.1540-4781.2009.00829.x

Bercicova, P. (2007). Teacher role in pair-work activities [Master's thesis, Masaryk University]. https://is.muni. cz/th/199495/pedf m/diplomova prace Teacher s Roles_in_Pair_Work.pdf

Berg, B. L., \& Lune, H. (2004). Qualitative research methods for the social sciences ( $5^{\text {th }}$ ed.). Pearson Education.

Blank, S. (1982). Undergraduate Research Projects as a Teaching and Learning Device. Western Journal of Agricultural Economics, 7(2), 221-226. https:// www.researchgate.net/publication/23948090 UNDERGRADUATE RESEARCH PROJECTS AS A TEACHING AND LEARNING DEVICE

Borg, S. (2009). English language teachers' conceptions of research. Applied Linguistics, 30(3), 358-388. https://doi.org/10.1093/applin/amp007

Borko, H., Liston, D., Whitcomb, J. A. (2007). Genres of empirical research in teacher education. Journal of Teacher Education, 58(1), 3-11. https://doi. org/10.1177/0022487106296220

Brydon-Miller, M., Greenwood, D., \& Maguire, P. (2003). Why action research? Action research. Action Research Plus, 1(1), 9-28. https://doi. org/10.1177/14767503030011002

Cárdenas-Ramos, R., \& Faustino, C. C. (2003). Developing reflective and investigative skills in teacher preparation programs: The design and implementation of the classroom research component at the foreign language program of Universidad del Valle. Colombian Applied Linguistics Journal, 5, 22-48. https://doi.org/10.14483/22487085.180

Castro-Garcés, A. Y., \& Martínez-Granada, L. (2016). The Role of Collaborative Action Research in Teachers' Professional Development. Profile Issues in Teachers
Professional Development, 18(1), 39-54. https://doi. org/10.15446/profile.v18n1.49148

Chaiklin, S. (2003). The zone of proximal development in Vygotsky's analysis of learning and instruction. Vygotsky's educational theory in cultural context, 1, 39-64. https://doi.org/10.1017/ CB09780511840975.004

Córdoba, E. (2013). Fostering risk-taking through pair work activities in an EFL setting: A case study. Opening Writing Doors Journal, 10(2), 25-53. http:// revistas.unipamplona.edu.co/ojs_viceinves/index. php/OWD/article/view/374/0

Córdoba, E. (2016). Implementing task-based language teaching to integrate language skills in an EFL program at a Colombian university. PROFILE Issues in Teachers' Professional Development, 18(2), 1327. https://doi.org/10.15446/profile.v18n2.49754

DiCicco-Bloom, B., \& Crabtree, B. F. (2006). The qualitative research interviews. Medical Education, 40(4), 314-321. https://doi.org/10.1111/j.13652929.2006.02418.x

Elliot, J. (1990). Educational research in crisis: performance indicators and the decline in excellence. British Educational Research Journal, 16(1), 3-18. https://doi.org/10.1080/0141192900160101

Fagan, D. S. (2015). When Learner Inquiries Arise: Marking Teacher Cognition as It Unfolds "In-TheMoment". Ilha do Desterro, 68(1), 75-90. https://doi. org/10.5007/2175-8026.2015v68n1p75

Gitlin, A., Barlow, L., Burbank, M. D. Kauchak, D., \& Stevens, T. (1999). Pre-service teachers' thinking on research: Implications for inquiry-oriented teacher education. Teaching and Teacher Education, 15(7), 753-769. https://doi.org/10.1016/S0742$\underline{051 X(99) 00015-3}$

Glaser, B. G. (2007). Constructivist Grounded Theory? Historical Social Research / Historische Sozialforschung. Supplement, 19, 93-105. http:// www.jstor.org/stable/40981071.

Guerra-Sánchez, J., Rodríguez-Vásquez, Z., \& DíazMosquera, C. P. (2015). Action research processes in a foreign language teaching program: Voices from inside. Colombian Applied Linguistics Journal, 17(2), 276-289. https://doi.org/10.14483/udistrital. jour.calj.2015.2.a07

Hagevik, R., Aydeniz, M., \& Rowell, C. G. (2012). Using action research in middle level teacher education to evaluate and deepen reflective practice. Teaching and Teacher Education, 28(5), 675-684. https://doi. org/10.1016/j.tate.2012.02.006

Hensel, N. (2012). Characteristics of Excellence in Undergraduate Research. The Council on 
Undergraduate Research. https://www.cur.org/ assets/1/23/COEUR final.pdf

Kreiner, G, Hollensbe, E, \& Sheep, M. (2006). Where is the "me" among the "we"? Identity work and the search for optimal balance. Academy of Management Journal, 49(5), 1031-1057. https://www.jstor.org/ stable/20159815

Kutlay, N. (2013). A survey of English language teachers' views of research. Procedia-Social and Behavioral Sciences, 70, 188-206. https://doi.org/10.1016/j. sbspro.2013.01.055

Lombard, B. J., \& Kloppers, M. (2015). Undergraduate student teachers' views and experiences of a compulsory course in research methods. South African Journal of Education, 35(1), 01-14. https:// doi.org/10.15700/201503070032

Lopatto, D. (2003). The essential features of undergraduate research. Council on Undergraduate Research Quarterly, 24, 139-142.

López-Alvarado, J. (2017). Educational Research: Educational Purposes, the Nature of Knowledge and Ethical Issues. Online Submission, 2(1), 1-5. http:// dx.doi.org/10.19239/ijrev2n1p1

McNulty Ferri, M. (2010). Action research topics and questions in a foreign language teaching practicum in Colombia. Íkala, revista de lenguaje y cultura, 15(24), 207-230. https://revistas.udea.edu.co/index. php/ikala/article/view/5104

Mello, H., Dutra, D. P., \& Jorge, M. (2008). Action research as a tool for teacher autonomy. DELTA: Documentação de Estudos em Lingüística Teórica e Aplicada, 24(SPE), 512-528. https://doi.org/10.1590/ S0102-44502008000300007

Mehrani, M. (2015). English teachers' research engagement: Level of engagement and motivation. Iranian Journal of Language Teaching Research, 3(1), 83-97. https://files.eric.ed.gov/fulltext/ EJ1127337.pdf

Ministerio de Educación Nacional (MEN) (2006). Lineamientos de Calidad de los programas de Licenciatura. El reto - Imprenta Nacional. https:// www.mineducacion.gov.co/1759/articles-357233 recurso 1.pdf

Ortlipp, M. (2008). Keeping and using reflective journals in the qualitative research process. The Qualitative Report, 13(4), 695-705. https://doi. org/10.46743/2160-3715/2008.1579

Pellerin, M., \& Nogués, F. I. (2015). Becoming reflective and inquiring teachers: Collaborative action research for in-service Chilean teachers. Revista Electrónica de Investigación Educativa, 17(3), 56-60. http:// www.scielo.org.mx/pdf/redie/v17n3/v17n3a4.pdf
Pérez, L. M., \& Alvira, R. (2017). The acquisition of vocabulary through three memory strategies. Colombian Applied Linguistics Journal, 19(1), 103116. https://doi.org/10.14483/calj.v19n1.10032

Petrella, J. K., \& Jung, A. P. (2008). Undergraduate research: Importance, benefits, and challenges. International Journal of Exercise Science, 1(3), 9-961. https://www.ncbi.nlm.nih.gov/pmc/articles/ PMC4739295/

Price, J. N. (2001). Action research, pedagogy and change: The transformative potential of action research in pre-service teacher education. Journal of Curriculum Studies, 33(1), 43-74. https://doi. org/10.1080/00220270118039

Raja, N., E Saeed, A. (2012). The effectiveness of group work and pair work for students of English at undergraduate level in public and private sector colleges. Interdisciplinary Journal of Contemporary Research in Business, 4(5), 155-163. http://journalarchieves23.webs.com/155-163.pdf

Reyes-Cruz, M. D., Rueda de León-Barbosa, L. I., \& Murrieta-Loyo, G. (2017). Undergraduate Preservice EFL Teachers' Conceptions of Research: A Quantitative Analysis. Colombian Applied Linguistics Journal, 19(1), 67-83. https://doi.org/10.14483/calj. v19n1.10534

Sert, O. (2005). A comparative analysis of pair-work and individual assignments in two ELT grammar classes. Journal of Language and Linguistic Studies, 1(2), 236-252. http://files.eric.ed.gov/fulltext/ED496120. pdf

Strauss, A., \& Corbin, J. (1994). Grounded theory methodology. Handbook of qualitative research, 17, 273-85. https://www.depts.ttu.edu/education/ our-people/Faculty/additional_pages/duemer/ epsy_5382_class_materials/Grounded-theorymethodology.pdf

Viáfara-González, J. (2008). Pedagogical Research in the Practicum at Universidad Nacional: EFL Pre-Service Teachers' Conceptions and Experiences. Matices en Lenguas Extranjeras, 2, 2011-117. http:// www.revistas.unal.edu.co/index.php/male/article/ view/10704/28095

Vygotsky, L. (1998). The collected works of LS Vygotsky (5 $5^{\text {th }}$ ed.): Child psychology. Translated by Marie J. Hall (Editor of the English Translation: Robert W. Rieber), Kluwer Academic/Plenum Publishers. https://www.springer.com/gp/book/9780306424410

Walkington, H. (2015). Students as researchers: Supporting undergraduate research in the disciplines in higher education. The Higher Education Academy.

Wallace, M. (2008). Action research for language teachers. Cambridge University Press. 
Ware, M. E., Badura, A. S., \& Davis, S. F. (2002). Using Student Scholarship to Develop Student Research and Writing Skills. Teaching of Psychology, 29(2), 151-154.https://creighton.pure.elsevier.com/en/ publications/using-student-scholarship-to-developstudent-research-and-writing

Weinberger, A., Patry, J. L., \& Weyringer, S. (2016). Improving Professional Practice through PracticeBased Research: VaKE (Values and Knowledge Education) in University-Based Teacher Education.
Vocations and Learning, 9(1), 63-84. https://doi. org/10.1007/s12186-015-9141-4

Wengraf, T. (2001). Qualitative research interviewing: Biographic narrative and semi-structured methods. SAGE. https://doi.org/10.4135/9781849209717

Zheng, H. (2009). A review of research on EFL pre-service teachers' beliefs and practices. Journal of Cambridge Studies, 4(1), 73-81. https://www.repository.cam. ac.uk/bitstream/handle/1810/255675/200901 article9.pdf?sequence $=1$ 
Pair Research Tasks: Promoting Educational Research with Pre-Service Teachers

\section{Appendix 1: List of pair-research tasks}

\begin{tabular}{|c|c|c|c|}
\hline Number & TASK & AIMS & Expected result \\
\hline 1 & $\begin{array}{l}\text { Educational research } \\
\text { background }\end{array}$ & $\begin{array}{l}\text { To get a general insight on what educational } \\
\text { research is }\end{array}$ & $\begin{array}{c}\text { Written and oral report of education } \\
\text { research }\end{array}$ \\
\hline 2 & $\begin{array}{l}\text { Educational research: a } \\
\text { need or a must for EFL } \\
\text { teachers }\end{array}$ & $\begin{array}{c}\text { To determine the need and the must of } \\
\text { conducting educational research for future EFL } \\
\text { teachers }\end{array}$ & $\begin{array}{l}\text { Written and oral report of educational } \\
\text { research in EFL education }\end{array}$ \\
\hline 3 & $\begin{array}{l}\text { Practical use of educational } \\
\text { research }\end{array}$ & $\begin{array}{c}\text { To know the process to conduct educational } \\
\text { research }\end{array}$ & $\begin{array}{l}\text { Written and oral report of practical } \\
\text { use of educational research }\end{array}$ \\
\hline 4 & Selecting a research topic & $\begin{array}{c}\text { To select a research topic according to the } \\
\text { significance and interests } \\
\text { To describe a research problem }\end{array}$ & $\begin{array}{l}\text { Written list of research interests } \\
\text { Description of a research problem } \\
\text { Justification to select such a problem }\end{array}$ \\
\hline 5 & $\begin{array}{l}\text { Stating research objectives } \\
\text { and questions }\end{array}$ & To state research objectives and questions & Research objective and question \\
\hline 6 & $\begin{array}{l}\text { Conducting a literature } \\
\text { review }\end{array}$ & To conduct a literature review & Literature review \\
\hline 7 & $\begin{array}{l}\text { Selecting the methodology } \\
\text { for a research study }\end{array}$ & $\begin{array}{l}\text { To select the appropriate methodology for a } \\
\text { research study }\end{array}$ & Methodology \\
\hline 8 & $\begin{array}{l}\text { Collecting data and } \\
\text { choosing participants }\end{array}$ & To collect data and choosing participants & $\begin{array}{l}\text { List of data collection methods and } \\
\text { sampling techniques }\end{array}$ \\
\hline 9 & $\begin{array}{l}\text { Designing data collection } \\
\text { instruments }\end{array}$ & To design data collection instruments & Pilot of data collection instruments \\
\hline \multirow[b]{2}{*}{10} & $\begin{array}{l}\text { Analyzing data and } \\
\text { reporting the findings }\end{array}$ & $\begin{array}{c}\text { To learn how to analyze data and report the } \\
\text { findings }\end{array}$ & Data analysis and interpretation \\
\hline & Final research proposal & To submit an educational research proposal & Research proposal \\
\hline
\end{tabular}




\section{Appendix 2: Summary of areas improved}

TASK

Selecting and stating a research topic

Stating research questions
AIMS

To select a research

topic according to significance and

interests

To describe a research problem

\section{Before}

Pair 1: Broad topic

Final result

Analyzing in Florencia

Pair 2: Broad topic

Task-based teaching in Colombia

Pair 3: Broad topic

English language teaching and learning Describing the English language teaching and process at the Colombian universities

Pair 4: Broad topic be used in class

Pair 5: Narrowed the topic

Current approaches to language teaching Pair 1: Broad question
How is oral interaction in English teaching in What is the effectiveness of teacher-made materials Florencia?

to foster oral interaction in English learning at a local school in Florencia?

Pair 2: Broad question Pair 2: Narrowed question What are the implications of applying task-based Why is task-based teaching used in Colombia? teaching at a public institution in the rural area of Florencia, Caquetá?

To state research questions

\section{Pair 3: Broad question}

Pair 3: Narrowed question

How is English language teaching and How is the English language teaching and learning learning process at Colombian universities? process at a public university in Florencia?

Pair 4: Broad question

Pair 4: Narrowed question

How many English teaching and learning What are the effects of contextualizing English approaches could be used in class?

teaching and learning approaches?

Pair 5: Broad question

Pair 5: Narrowed question

What are the current approaches to language What are the differences among current approaches teaching?

to language teaching and learning?

Pair 1: Broad objective Pair 1: Narrowed objective

To analyze the effectiveness of teacher-made in Florencia

materials to foster oral interaction in English learning at a local school in Florencia

Pair 2: Broad objective

Pair 2: Narrowed objective

To explore the implications of applying task-based To compare task-based teaching in Colombia teaching at a public institution in the rural area of Florencia, Caquetá

Pair 3: Broad objective

Pair 3: Narrowed objective

Stating general

research

objectives
To state research objectives
To know English language teaching and To describe the English language teaching and
learning process at Colombian universities learning process at a public university in Florencia

Pair 4: Broad objective

Pair 4: Narrowed objective

To make English teaching and learning easy To contextualize English teaching and learning through approaches to be used in class approaches in a rural school in Florencia

Pair 5: Broad Objective

Pair 5: Narrowed objective

To know current approaches to language To compare and contrast current approaches to teaching language teaching and learning 